\title{
O BRASIL E 0 MERCOSUL: ATORES DOMÉSTICOS E OSCILAÇÕES DA POLÍTICA EXTERNA NOS ÚLTIMOS 30 ANOS
}

\author{
Marcelo Passini Mariano ${ }^{a}$ \\ aProfessor de Relações Internacionais da Universidade Estadual Paulista (UNESP). \\ Franca, SP, Brasil].E-mail: marcelopmariano@gmail.com
}

Orcid: 0000-0002-1159-2537

Haroldo Ramanzini Júnior ${ }^{b}$

- Professor Associado do Instituto de Economia e Relações Internacionais da Universidade Federal de Uberlândia (UFU). Uberlândia, MG, Brasil.

E-mail:hramanzinijunior@gmail.com

Orcid: 0000-0001-7105-6237

Tullo Vigevanic

cProfessor de Ciência Política e Relações Internacionais da Universidade Estadual Paulista (UNESP). Marilia, SP, Brasil. E-mail: vigevanit@uol.com.br

Orcid: 0000-0001-6698-8291

http://dx.doi.org/10.1590/0102-015054/112

\section{Introdução ${ }^{1}$}

O objetivo deste artigo é analisar o papel do Mercosul na política externa brasileira e a importância comercial do bloco para o Brasil no período de 1991 a 2021. O bloco completa trinta anos demonstrando importante capacidade de resiliência, apesar do contexto de menor engajamento dos países, dos efeitos acumulados das sucessivas crises políticas

1 Agradecemos o apoio de André Mellini na coleta e sistematização dos dados de comércio utilizados neste texto. 
e comerciais e da diminuição da interdependência econômica. O contexto global dos anos 2020 - de acirramento das disputas geopolíticas entre Estados Unidos e China, de dificuldades para a cooperação multilateral e de fortalecimento de forças políticas conservadoras em diferentes países do mundo - traz novos desafios para os processos que buscam a integração regional, e para o Mercosul, em particular, alguns totalmente imprevisíveis quando da formação do bloco, em 1991. Nesse contexto, a limitada estrutura institucional para fazer frente aos desafios estimula dúvidas quanto ao futuro do Mercosul.

Este artigo tem como principal argumento a existência de uma trajetória de gradual perda de centralidade do bloco para a política externa brasileira e de redução nos níveis de intercâmbio comercial. Esse importante declínio tem origem principalmente nas atitudes de parte das elites ${ }^{2}$ e de grupos de interesse que contribuem para os mecanismos de decisão do Estado. Assim, o declínio da prioridade do bloco para o Brasil, observado nos governos Temer e Bolsonaro (Vadell e Giaccaglia, 2020), não deve ser visto como fato desenraizado de problemas que já se manifestavam nos governos anteriores, em verdade desde 1995, ainda que com diferentes características. Nestes trinta anos, as elites empresariais e políticas brasileiras não mantiveram o mesmo interesse pela integração. A situação de forte instabilidade que levou ao impeachment da presidente Dilma Rousseff, em 2016, e se seguiu nos governos Temer e Bolsonaro contribuiu para aprofundar ainda mais a crise do bloco, realimentada por um novo contexto em que o enfraquecimento da capacidade centrípeta do Mercosul liga-se a uma onda hemisférica que resultou no rebaixamento dos objetivos de autonomia.

\footnotetext{
2 Consideramos neste artigo o conceito de elite desenvolvido por Dahl (1958, p. 464): "A ruling elite, then, is a controlling group less than a majority in size that is not a pure artifact of democratic rules. It is a minority of individuals whose preferences regularly prevail in cases of differences in preference on key political issues".
} 
Ressalta-se que, numa perspectiva histórica, a autonomia é objetivo de qualquer Estado-nação e suas características se adaptam ao longo do tempo: "As expressões do que é autonomia variam histórica e espacialmente, variam segundo interesses e posições de poder" (Fonseca Júnior, 1998, p. 361). O conceito admite diferentes abordagens segundo a configuração de um determinado período histórico, bem como das visões de mundo da população e das elites. No caso do Brasil, na maior parte do tempo o Mercosul não foi visto como limitador de sua autonomia - ao contrário, o compartilhamento de interesses aumentaria as capacidades externas. A ideia de autonomia na segunda metade dos anos 1980, e ainda para uma parte da sociedade e da alta burocracia do Estado nos anos 1990 e até o final do governo Lula, significou autonomia em relação ao mundo exterior, capacidade de decisão diante dos centros de poder internacional, viabilizando ao Brasil determinar suas escolhas.

No entanto, as transformações do sistema internacional no início dos anos 2000 e seu impacto na percepção das elites a respeito do papel que o Brasil deveria desempenhar no mundo não foram suficientemente absorvidas como incentivos sistêmicos para o aprofundamento da integração regional. Trata-se de dificuldade do Estado e das elites políticas em visualizar o âmbito regional como uma instância apta a efetivamente promover seus interesses, sejam econômicos ou políticos. Por isso, as posturas dos que encabeçavam o Estado brasileiro em relação à integração, ao menos até 2016, foram pautadas por um real interesse, mas esse interesse vinculou-se, também, ao objetivo de garantir melhores condições de inserção em outras arenas internacionais.

É importante ter em conta que, desde 1985, a integração no Cone Sul conviveu com diferentes ambientes externos, evoluindo de tentativas desenvolvimentistas (1985-1988) para formas de regionalismo aberto (1989-2002), inseridas num clima internacional de regimes liberais. Em seguida, 
com a presença de governos desenvolvimentistas e distributivistas (2003-2015), no período chamado pós-hegemônico (Riggirozzi e Tussie, 2012), os países buscaram fortalecer as diferentes instâncias de integração, cooperação e articulação regional, buscando consolidar o multilateralismo sem voltar ao protecionismo. A partir de 2016, o governo Mauricio Macri na Argentina e o impeachment de Rousseff fortaleceram os movimentos contrários à integração, particularmente no Brasil. Esta tendência se intensificou a níveis previamente inimagináveis com a administração de Jair Bolsonaro a partir de 2019.

Assim, analisaremos neste artigo os elementos de continuidade e de mudança no comportamento brasileiro - do governo, de empresários e da sociedade civil - em relação ao Mercosul e à integração, bem como o impacto das transformações do cenário mundial e do comércio exterior nas posturas desses atores. Abordaremos não apenas as transformações econômicas, mas também as consequências do enfraquecimento político do multilateralismo e da acentuação das tensões político-econômico-estratégicas. Nesta trajetória, as atitudes das elites brasileiras se combinaram com as mudanças objetivas ocorridas no cenário econômico e político mundial desde o fim dos anos 1980 até 2021.

Uma dessas mudanças do cenário externo foi o crescimento da economia mundial, de 2001 até 2008, com destaque para o papel da China, que levou setores empresariais e grupos importantes no governo a reorientar o foco de seus interesses (Paikin e Dulcich, 2017). Ainda que mantida a ênfase política na integração, ela teve seu significado proporcionalmente reduzido. $\mathrm{O}$ aumento do preço das commodities, inclusive do petróleo e do gás, bem como a liquidez observada no sistema financeiro nos primeiros anos do século XXI colaboraram para o aumento das exportações não só do Brasil, mas também dos outros países da região. Ainda que não tenha contribuído para o esforço de 
complementaridade produtiva e comercial regional, o bom momento internacional foi importante para que os países mantivessem suas economias razoavelmente estáveis.

A recessão nos países centrais, fruto da crise de 2008, poderia sugerir um novo ciclo favorável à integração na América do Sul exatamente pela contração dos mercados dos países centrais e pela existência de fortes convergências entre as lideranças políticas dos principais países da região no período pós-hegemônico. Contudo, a crise internacional desencadeada pela falência do Lehman Brothers começa a ser superada já em 2010, com o crescimento ininterrupto das economias norte-americana e chinesa, que perdurou até a pandemia de covid-19.

Com isso, observa-se um traço geral: ao não existirem forças econômicas internas nos países do Mercosul decididamente favoráveis à integração econômica, o contexto internacional, seja de crise (crise de 2008, pandemia de 2020), seja de crescimento (como a primeira década dos anos 2000 até aproximadamente 2013), não trabalhou a favor da integração regional e da integração produtiva.

Partimos da hipótese de que as transformações do cenário mundial e do comércio exterior do país influenciaram fortemente as posturas do Brasil em relação ao Mercosul. A crise financeira e econômica internacional, desencadeada a partir do segundo semestre de 2008, pareceu, até 2016, não alterar a tendência de busca por fortalecer o papel do país no mundo. O Brasil, mesmo nas situações em que houve efetivo interesse pela integração, o que se deu desde 1985, talvez desde o Acordo Tripartite de 1979, também nos governos Cardoso, Lula e Rousseff, não desenvolveu capacidades de agência para impulsionar decisivamente o processo, em função de interesses contraditórios de parte importante das elites e das fragilidades estruturais do país, em particular a forma de inserção no sistema econômico e político internacional. $\mathrm{O}$ fato de os países do Mercosul se inserirem na 
economia mundial de forma semelhante, como exportadores de produtos primários e commodities, e terem baixos níveis de poupança interna, sendo, portanto, dependentes de financiamento e da tecnologia externa, torna-os vulneráveis às oscilações dos preços internacionais de commodities e subordinados a dinâmicas extrarregionais (Krapohl, 2020; Ramanzini Júnior e Luciano, 2020). No caso do Brasil no Mercosul, a baixa disposição de agência desenvolvida nestes trinta anos perpetuou essa vulnerabilidade. Do mesmo modo, como veremos nas seções seguintes, as dificuldades para ampliar a interdependência econômica regional trouxeram desafios adicionais para a integração, particularmente no que se refere ao engajamento das elites econômicas.

A arquitetura do Mercosul, tal como construída em 1991 e em 1994 e válida, ao menos formalmente, até hoje (2021), pareceu atender aos interesses das elites brasileiras. Esse formato de integração foi adequado para dar a 20 sustentação considerada possível, ou a liberdade desejada, às ações internacionais do país na Organização Mundial do Comércio (OMC), nas relações com os Estados Unidos e com a União Europeia e nos G20 financeiro e comercial. Esse formato possibilitou ao país ter relativa independência diante dos constrangimentos de uma União Alfandegária em pleno funcionamento apoiada em maiores níveis de institucionalização (Lima, 2018). Vista em retrospecto, pode-se afirmar que esta perspectiva enfraqueceu a integração, permitindo que o papel centrípeto dos Estados Unidos voltasse a pesar significativamente (Kacowicz, 2016). Do ponto de vista econômico, o da China também.

Conceitualmente, este artigo está em consonância com o argumento de Mattli (1999a) sobre as principais fragilidades das abordagens teóricas que tratam dos fenômenos de integração regional. De um lado, as principais abordagens das relações internacionais sobre integração regional (Haas, 1958; Moravcsik, 1995; Schmitter, 1970, 2010) contemplam 
parcialmente as dinâmicas econômico-comerciais, assim como as abordagens econômicas que tratam da integração de mercados não incorporam adequadamente os aspectos político-institucionais envolvidos. Segundo Mattli (1999a, p. 8, tradução nossa),

uma análise da integração de mercado que negligencia a incorporação dos elementos institucionais corre o risco de ser vazia. A integração de mercado ocorre em um ambiente institucional específico. Também traz consigo implicações institucionais que, por sua vez, afetam o curso da integração de mercado. Um relato de integração que busca abordar os aspectos dinâmicos do fenômeno deve considerar a relação recíproca entre fatores econômicos e político-institucionais.

Sem ter a pretensão de resolver este problema teórico, o presente artigo mantém o foco sobre o Brasil para entender o seu papel como principal membro do Mercosul, analisando os fatores políticos e institucionais sem desconsiderar o papel fundamental da integração comercial. Da mesma forma que nas principais abordagens sobre integração regional, o artigo admite a importância das elites e procura incorporar os conceitos de paymaster e de demanda por integração de Walter Mattli (1999a, 1999b). Busca-se assim compreender a dinâmica do bloco nestes trinta anos, lembrando que o papel das elites na política brasileira é amplamente amparado por autores como Florestan Fernandes (1987) ou Raymundo Faoro (1975). Sem aqui discuti-los, lembramos sua importância para situar o debate sobre as elites e seu papel.

Tendo em conta os aspectos mencionados, na seção seguinte discutiremos os elementos de continuidade e de mudança da política externa brasileira em relação ao Mercosul, e também as persistentes dificuldades para construir a capacidade de agência para a integração regional. 
Na terceira seção, analisaremos os aspectos comerciais da integração, as mudanças verificadas no comércio exterior brasileiro e suas consequências para o bloco. Por fim, nas considerações finais retomaremos os principais aspectos discutidos e sinalizaremos os novos desafios que a integração tem enfrentado desde 2019.

\section{A trajetória da política externa brasileira, as dificuldades estruturais e 0 (des)encontro com a Argentina e o Mercosul}

A partir da década de 1980, no bojo da crise da dívida externa, da alta inflação, da estagnação econômica e da mudança de regime político, acentuou-se o debate em parte das elites brasileiras no sentido de repensar o modelo de desenvolvimento econômico do país. Ganhou força a percepção de que o Brasil deveria ter uma postura mais participativa em relação às grandes questões internacionais.

22 O caminho encontrado pelos formuladores da política externa brasileira para garantir maior inserção internacional no mundo pós-Guerra Fria foi a busca de maior participação em organizações e regimes internacionais e a adoção de iniciativas visando a integração regional (Fonseca Júnior, 1998).

No início dos anos 1990, a atuação internacional do Brasil foi redirecionada buscando fortalecer sua posição diante dos novos desafios, particularmente aqueles definidos pela tendência à formação de blocos regionais, efetivando uma estratégia presente desde a segunda metade dos anos 1980. Desde seu surgimento, o Mercosul foi considerado base da estratégia de inserção internacional do Brasil. Apesar disso, desde 1991 há uma permanente tensão entre as necessidades estruturais da integração e as atitudes e posições de importantes atores sociais e governamentais do Brasil. Neste sentido, com o objetivo de evitar a adesão a arranjos que pudessem limitar as futuras opções do país, 
houve convergência, ainda que baseada em motivações diferentes, entre setores ligados à perspectiva nacional-desenvolvimentista e aqueles ligados à tradição liberal (Barbosa, 1996; Guimarães, 2006). Entre 1991 e 2020, essa convergência teve um impacto direto nas posições brasileiras em relação à integração.

No momento da aproximação Brasil-Argentina, em meados dos anos 1980, houve uma superposição entre a ideia da integração regional, a aliança com a Argentina e a preservação dos valores do universalismo e da autonomia presentes na política externa brasileira. Para o Brasil, o interesse nacional estaria contemplado em um processo de integração abrangente, incorporando visões do empresariado nacional e também de grupos multinacionais, especialmente do setor automotivo (Vigevani e Veiga, 1997). Nesse contexto, o regionalismo não diminuiria, mas reforçaria o paradigma universalista de inserção internacional do Brasil. A percepção do risco de isolamento como consequência do fim da Guerra Fria (Moreira, 1989) e o reconhecimento de que as debilidades internas dos países enfraqueceriam suas posições externas foram importantes para o processo de integração Brasil-Argentina e, posteriormente, para a inclusão do Paraguai e do Uruguai. Contudo, essa superposição entre a integração regional, a aliança com Argentina e as orientações internacionais autonomistas e universalistas foi se diluindo com o passar dos anos.

Em meados dos anos 1980, quando a política brasileira empreendeu o caminho do estreitamento das relações com a Argentina, a ideia do universalismo não foi abandonada, mas ganhou novo significado. Houve a tentativa de entrelaçar interesse nacional com interesse regional do Cone Sul.

A aliança estratégica Argentina-Brasil foi assinada pelos presidentes Fernando Henrique Cardoso e Carlos Menem em abril de 1997 (Gonçalves e Lyrio, 2003). As crises econômicas nas relações intra-Mercosul, determinadas pela 
desvalorização não negociada do real em 1999 e o fim da paridade peso-dólar na Argentina em 2001, ainda que determinadas por graves crises financeiras e políticas internas, foram abalos significativos e dão início a desconfianças que perduraram ao longo dos anos (Camargo, 2006; Gazzola, 2017). Como veremos na seção seguinte, as relações econômicas entre Brasil e Argentina continuam suficientemente importantes ao longo do tempo, mesmo no período Temer e também na conturbada administração Bolsonaro, mas passaram a ser vistas cada vez mais como tendo menor peso relativo. Ministros e chefes de Estado no Brasil foram progressivamente diminuindo seu significado.

Uma questão relevante quando analisamos o Mercosul e a política externa brasileira é considerar que se trata de um processo de integração regional que envolve quatro países com características significativamente distintas, embora todos sejam países em desenvolvimento.

24 Como podemos observar na Tabela 1, o Brasil é o país que, de longe, tem a maior dimensão territorial, e o mesmo ocorre em relação à população e à economia. Porém, se observarmos os indicadores de desenvolvimento humano e de produto interno bruto (PIB)/paridade de poder de compra (PPC), Uruguai e Argentina são países que, nessa perspectiva, são mais ricos do que o Brasil. Isso coloca uma situação estrutural bastante delicada para o Mercosul, pois há dificuldades de corresponder às expectativas que os países vizinhos manifestam em relação ao Brasil, no sentido de pagar ao menos em parte os custos da integração e contribuir para o desenvolvimento dos outros membros do bloco.

No esquema analítico desenvolvido por Walter Mattli (1999b), para que um processo de integração regional seja bem-sucedido é necessário que o bloco apresente algumas condições. Para esse autor, uma importante condição é que "um Estado-membro dominante de um agrupamento 
regional deveria ser capaz e querer assumir o papel de paymaster regional, aliviando as tensões distributivas e, assim, suavizando o caminho da integração" (Mattli, 1999b, p. 170, tradução nossa).

Diante dos dados da Tabela 1, podemos verificar que a capacidade do Brasil para desempenhar este papel possui limitações estruturais, em razão de suas características sociais e econômicas.

No entanto, o conceito de paymaster não se refere apenas às capacidades do principal Estado do bloco, mas também à sua disposição em assumir o papel esperado. Assim, a disposição em arcar com os custos da integração também possui limitações estruturais, pois a desigualdade social e as diferenças regionais características do Brasil dificultam as ações dos governos nesse sentido, mesmo que o público brasileiro pouco discorde de o país ajudar os países menos desenvolvidos da América do Sul, não ultrapassando os 20,1\% dos entrevistados em levantamento realizado em 2014 (Almeida et al., 2017). No entanto, justificar o direcionamento de recursos para os países do Mercosul é uma questão muito sensível, já que os indicadores econômicos e sociais desses mesmos países estão mais bem posicionados, com exceção do Paraguai. Na mesma linha, Hummel e Lohaus (2012, p. 17, tradução nossa) afirmam: "baixo PIB per capita, alto índice de pobreza e enorme desigualdade no Brasil fornecem bons argumentos contra as transferências para os vizinhos mais abastados na Argentina e no Uruguai”.

Em outros termos, a expectativa de o Brasil ser um paymaster (Mariano, 2015; Mattli, 1999b) regional é frequentemente frustrada. Em diversas ocasiões, essa condição potencial de paymaster se reflete na vontade política concentrada nos presidentes e na estratégia de realizar concessões pontuais em momentos críticos como forma de compensar as dificuldades estruturais e a baixa disposição nacional em criar políticas regionais efetivas de compensação das 
assimetrias entre os países. Isso explica, em parte, a forte resiliência do bloco diante das frequentes situações de crises políticas e econômicas que marcam a história da região. Hummel e Lohaus (2012, pp. 24-25, tradução nossa) argumentam ainda

que o Mercosul tem se mostrado mais bem-sucedido do que as teorias convencionais sobre integração regional nos levam a crer, mas apresenta certas particularidades, como seu desenho institucional muito limitado e um histórico problemático no que diz respeito à implementação interna das decisões regionais. O papel dominante dos presidentes, especialmente os da Argentina e do Brasil, e os baixos níveis de interdependência econômica ajudam a compreender esses resultados. Parece que foram as iniciativas presidenciais que permitiram que a organização regional se formasse, apesar das condições econômicas adversas, e continuasse durante grandes crises. Estes últimos também foram mitigados pelo terceiro tipo de liderança regional, o papel dos estados dominantes como paymasters. Mais do que por meio de fundos regionais, o Brasil parece cumprir esse dever indiretamente, fazendo concessões políticas contra seus interesses econômicos em situações críticas.

Os dados da Tabela 1, mostrando de forma expressiva as radicais diferenças entre os PIBs nacionais e o PIB PPC, isto é, entre o peso da economia de cada país e o nível de vida dos cidadãos, ajuda a explicar o impulso baixo para o spillover, ${ }^{3}$ sobretudo no Brasil.

\footnotetext{
3 O conceito de spillover foi desenvolvido por Ernst B. Haas (1958) para compreender os processos de integração regional, no qual a integração de um setor tende a se espalhar para outros, sendo acompanhada de uma mudança de comportamento dos governos e de grupos domésticos no sentido de estabelecer novas lealdades em relação às instituições regionais em construção.
} 
Tabela 1

Informações geográficas, sociais, demográficas e econômicas entre os membros do Mercosul em 2018

\begin{tabular}{ccccc}
\hline País & $\begin{array}{c}\text { Área } \\
\mathbf{( k m}^{\mathbf{2}}\end{array}$ & $\begin{array}{c}\text { IDH } \\
\mathbf{( \# 1 8 9 )}\end{array}$ & $\begin{array}{c}\text { População } \\
\text { (milhões) }\end{array}$ & $\begin{array}{c}\text { PIB Nominal } \\
\text { (bilhões de USD) }\end{array}$ \\
\hline Argentina & $2,780,400$ & $0.83(\# 48)$ & 44.560 & 519.49 \\
Brasil & $8,515,770$ & $0.761(\# 79)$ & 208.495 & 1867.82 \\
Paraguai & 406,752 & $0.724(\# 98)$ & 7.053 & 41.85 \\
Uruguai & 176,215 & $0.808(\# 57)$ & 3.506 & 59.65 \\
\hline \multirow{5}{*}{ País } & PIB PPC & PIB Nominal PC & $\begin{array}{c}\text { PIB PPC PC } \\
\text { (USD }\end{array}$ \\
\hline Argentina & 915.75 & $11,658.22$ & $20,551.04$ \\
Brasil & $3,366.38$ & $8,958.58$ & $16,146.09$ \\
Paraguai & 94.51 & $5,934.18$ & $13,399.77$ & \\
Uruguai & 81.19 & $17,014.13$ & $23,157.97$ & \\
\hline
\end{tabular}

IDH: Índice de Desenvolvimento Humano; PIB: produto interno bruto; USD: dólar americano; PPC: paridade de poder de compra; PC: per capita.

Fonte: Elaboração própria, com base em dados da CIA (2021), do PNUD (2020) e do FMI (2019).

O tema do desenvolvimento no âmbito integracionista perdeu parte da importância na década de 1990, em virtude de resistências corporativas e sub-regionais domésticas no tocante ao aprofundamento do Mercosul, mesmo que os compromissos assumidos com a integração tenham sido mantidos pelos governos do período. Com a desvalorização do real em 1999 e a posterior recessão argentina em 2001, o Mercosul evidenciou uma crise cujos desdobramentos não foram claros de imediato. Além dos elementos conjunturais, que se expressaram por seguidos contenciosos comerciais e políticos, e da ausência de mecanismos institucionais regionais que buscassem garantir a dinâmica da integração, questões estruturais, relativas às economias dos países envolvidos e a valores enraizados nos Estados e nas sociedades, devem também ser consideradas na busca de explicações consistentes. 
A partir de 1996/1997 se conjugaram problemas comerciais específicos e significativos desentendimentos sobre a inserção internacional do país. Ganha peso a percepção de que o Mercosul estreitaria a capacidade universalista do Brasil em setores da Federação das Indústrias do Estado de São Paulo, da Confederação Nacional da Indústria, das entidades representativas do agribusiness, entre altos funcionários do governo e também na imprensa. Naquele momento, colaboraram para a inflexão do papel da integração o aparente avanço das negociações para a criação da Área de Livre Comércio das Américas (Alca), as negociações para o início de uma nova rodada de negociações na OMC concretizadas com a Conferência de Doha em novembro de 2001 e o começo da discussão sobre o papel dos grandes países não centrais, que se fortaleceu anos depois e ganharia o nome de Bric (Brasil, Rússia, Índia e China). ${ }^{4}$ Todas essas negociações ou orientações não deveriam necessariamente enfraquecer o Mercosul, mas isso acabou acontecendo, pois a ideia da integração não estava assimilada com a devida profundidade pelo conjunto das elites brasileiras. Ainda assim, em 2005, o diplomata brasileiro Alessandro Candeas (2005, p. 33) afirmava que:

a intensificação dos laços sociais e culturais em todos os níveis permitirão "internalizar" uma cultura de amizade e construir a "sociedade estratégica", suplantando os resquícios de rivalidade e equilíbrio de poder. Segundo pesquisa realizada por Mora y Araújo [...], há disposição extremamente favorável para tanto na sociedade argentina. As conclusões da sondagem de opinião são eloqüentes: o Brasil é o país com quem a Argentina mais deveria estreitar vínculos (36\%), superando Europa, Estados Unidos e Ásia.

4 Em 2011, a África do Sul é incluída no grupo e o acrônimo ganha um "S", transformando-se em Brics. 
O crescimento das oportunidades extrarregionais e a menor propensão das elites em fortalecer o Mercosul acabou por reduzir o que Mattli (1999a) chama de "demanda por integração", que ocorre quando as transações intrarregionais aumentam e são estimuladas por uma lógica de ganhos econômicos que se alimenta da economia de escala, do desenvolvimento tecnológico e das vantagens competitivas regionais. Como consequência, ampliam-se custos variados advindos dos problemas que naturalmente surgem quando as transações aumentam, como conflitos comerciais ou instabilidade doméstica nos países participantes. Como resultado, cresce a demanda por uma maior estrutura de governança, principalmente por parte dos agentes econômicos, como forma de diminuir a instabilidade decorrente da maior interdependência econômica.

Para que isso ocorra, é preciso que as expectativas estejam predominantemente voltadas para o aprofundamento da integração regional. Não foi isso o que se viu no caso do Mercosul na década de 2000, pois as mudanças no sistema internacional contribuíram para o fortalecimento das percepções positivas em relação às oportunidades extrabloco. $\mathrm{O}$ interesse de parte da sociedade brasileira pelo Mercosul e seu possível aprofundamento foi reduzido, tornando-se em alguns casos abertamente contrário a ele. Lembremos, como exemplo, que o encontro realizado em novembro de $2004-$ que reuniu empresários de diversos segmentos e entidades como a Federação das Indústrias do Estado de São Paulo, Associação Brasileira das Indústrias de Calçados, Associação Nacional de Fabricantes de Produtos Eletroeletrônicos e Associação de Comércio Exterior do Brasil - revelou ser razoável a oposição ao bloco regional. As discussões giraram em torno da ideia de defender um recuo em relação ao Mercosul: no meio empresarial, discutia-se a necessidade de retroceder de uma união alfandegária, considerada imperfeita, para uma área de livre comércio. Segundo o grupo 
reunido, o Mercosul seria uma âncora que aprisionaria o Brasil nas negociações internacionais, dificultando acordos bilaterais com os Estados Unidos e a União Europeia (Empresários..., 2004).

As análises que resultam das preocupações de parcela dos empresários confirmam a tendência de reduzir o significado da integração para o Brasil e do papel que o Mercosul tem para a política exterior e como referência na estratégia econômica e comercial internacional. Em geral, essas análises reiteravam o papel de freio que o Mercosul e a integração sul-americana exerceriam, dificultando um maior dinamismo externo do Brasil. Mesmo com o governo a sustentando, a integração comercial - objetivo mantido pelo governo Lula e também no período Rousseff, ainda que enfraquecido - mostrou crescentes dificuldades para avançar, como veremos nas tabelas a seguir. A preocupação com os países centrais, com economias diversificadas, com forte capacidade de importação de produtos sofisticados e de matérias-primas e bens agrícolas, na ótica do universalismo e do global trader, deveria prevalecer. Fonseca e Marconini (2006, p. 9) afirmam: "seria altamente recomendável que as autoridades brasileiras em futuro próximo tivessem a ousadia realista de converter o Mercosul, extinguindo o cada vez mais problemático regime de união aduaneira, para tornar-se uma área de livre-comércio".

Nos anos 2000, a potencial perspectiva de ganhos de escala em termos econômicos, que alguns acreditavam poder ser fortemente estimulada pelo acesso aos maiores mercados, levou à retomada dos temas da autonomia e do universalismo, que nunca foram abandonados, agora com um sentido restritivo em relação ao Mercosul, diferentemente do que se colocava no momento de constituição do bloco.

Portanto, visto retrospectivamente, na visão brasileira o Mercosul surge e se desenvolve de forma claramente ambígua, o que não é essencialmente diferente no caso 
argentino. Colocado no topo das prioridades internacionais, o Mercosul é apresentado como instrumento muito importante, mas sempre instrumento. Não haveria uma clara especificidade da integração, que não seria um fim em si mesma, e não há maior atenção em relação às questões de construção institucional. Já no momento de constituição do Mercosul, os governos o explicitaram: a perspectiva era a inserção competitiva global para a qual o bloco seria uma plataforma de grande interesse (Brasil, 1991). Isto é, o bloco visa a inserção internacional; desde o início, a questão da identidade e de construção de um aparato institucional que trabalhasse a partir de uma perspectiva regional não se colocou como objetivo central.

Podemos dizer que nas relações do Brasil com seu entorno mais próximo, o Mercosul e a América do Sul, a ideia de autonomia se manifesta, desde o início dos anos 1990, sob a forma de insistente revalorização da potencialidade de ação nacional específica, não sujeita às amarras que uma integração institucionalizada poderia acarretar (Ramanzini Júnior e Mariano, 2018). Nesse sentido, Almeida (1993, p. 138) considera que

o bom senso recomendaria a implementação de uma supranacionalidade limitada ao estrito indispensável para o funcionamento de uma união alfandegária plena. Em qualquer hipótese, não há por que reproduzir no Mercosul a enorme burocracia comunitária constituída ao longo dos anos na Comunidade Europeia, uma verdadeira "eurocracia" intervencionista usurpando parte da competência nacional dos países-membros.

Portanto, no esquema analítico de Mattli (1999a, 1999b), verifica-se que no Mercosul a outra condição fundamental para o desenvolvimento dos processos de integração não é plenamente observada: 
a fim de melhorar o cumprimento das regras de cooperação, um grupo de países que buscam a integração deve estabelecer "instituições de compromisso" [...] o fracasso em satisfazer essa condição não torna necessariamente a integração impossível, mas torna o sucesso mais difícil. As instituições de compromisso aumentam as chances de cooperação sustentada, agindo como restrições precisamente nas circunstâncias em que as medidas de autoajuda por si só são insuficientes para evitar a renúncia. Finalmente, as instituições de compromisso são mais eficazes se oferecerem acesso direto aos indivíduos com maior interesse em ver a integração concluída; exemplos aqui são o Tribunal de Justiça Europeu e a Comissão das Comunidades Europeias. (Mattli, 1999a, p. 14, tradução nossa)

Do começo dos anos 1990 até 2014, houve o fortalecimento crescente do paradigma universalista da política externa brasileira, que se relaciona com o entendimento das possibilidades do sistema internacional para a projeção internacional do país. No contexto do conceito de autonomia pela participação, evoluindo no governo Lula para a ideia de autonomia pela diversificação, intensificou-se a ação de maior inserção ativa do Brasil. Isso acontece mediante a intensa participação nas diversas organizações internacionais, nas Missões de Paz organizadas pelas Nações Unidas (ONU), como exemplifica o caso do Haiti, na busca pelo assento permanente no Conselho de Segurança da ONU, na articulação de coalizões multilaterais, como o G20 comercial na Rodada Doha da OMC, no grupo Índia, Brasil e África do Sul (Ibsa) e no grupo Brics.

Um aspecto da política externa brasileira no período desenvolvimentista-distributivista, com raízes anteriores, foi o de buscar garantir uma coesão mínima no Mercosul de forma a utilizar a integração como plataforma para sua 
inserção internacional (Mariano, 2015). Da mesma forma, utilizar o Mercosul como a base da estratégia de integração sul-americana também tem sido um componente importante nas posições regionais do país, daí, inclusive, a necessidade de manter um aparato institucional essencialmente intergovernamental que garanta a possibilidade de ingresso de novos membros. O esforço de integração da América do Sul demonstrou haver uma dimensão sul-americana do Estado brasileiro e, ao mesmo tempo, significou a busca de soluções alternativas a uma integração em profundidade no Cone Sul, como forma de evitar as consequências e os compromissos que ela implicaria (Desiderá Neto, 2014).

A posição dos diferentes governos brasileiros de 1986 a 2016, visando continuar a baixa intensidade da integração, parece atender à média das expectativas das elites, dentro e fora do aparelho estatal brasileiro. Mesmo com as mudanças radicais introduzidas a partir de 2016 na política exterior, mas sobretudo depois de 2019, o posicionamento das elites empresariais não mudou totalmente. Importante documento da Confederação Nacional da Indústria publicado em 2020, ou seja, na gestão Bolsonaro, defende a continuidade do Mercosul pelas vantagens que traz para algumas cadeias industriais brasileiras (Confederação Nacional da Indústria, 2020). Estes interesses ajudam a entender a situação de continuidade de baixa intensidade dos compromissos brasileiros em relação ao bloco.

\section{As mudanças internacionais, os aspectos comerciais e suas consequências para a política brasileira em relação ao Mercosul}

$\mathrm{O}$ peso atribuído às negociações multilaterais na esfera da OMC, bem como as movimentações dos Estados Unidos, ao menos desde o início dos anos 1990, no sentido de aprofundar as discussões sobre a integração hemisférica, ou de efetivar acordos bilaterais com países da região, em 
particular do Mercosul, foram fatores exógenos importantes que pautaram as posições brasileiras em relação ao bloco regional do Cone Sul. Como argumenta Mello (2000), na década de 1990 o objetivo norte-americano de avançar para a integração hemisférica resultou no fortalecimento do compromisso brasileiro com o Mercosul. Esse compromisso, no entanto, não foi suficiente para sustentar o aprofundamento da integração.

Depois da conferência de chefes de Estado e de governo das Américas em Mar del Plata, em 2005, quando houve coincidência na ação visando o adiamento sine die das negociações da Alca, o Mercosul teve reduzido o seu significado como instrumento de barganha em relação aos Estados Unidos. Isso pode ser comprovado pelas dificuldades de coordenação de políticas nas negociações da OMC, inclusive na importante reunião de Genebra de julho de 2008. Referindo-se a esse fato, o então presidente Lula da Silva afirma que "não houve divergência de conceitos", mas reconhece que muitas vezes, em momentos críticos, prevalece nas decisões do governo o interesse nacional:

Veja, por mais que você trabalhe para um processo de integração, seja da União Europeia ou da América do Sul ou do mundo asiático, em alguns momentos você tem que considerar a situação do seu Estado nacional. Não devemos ver, em nossas diferenças, situações de conflito, mas situações de diferença; diferenças econômicas e de potencial industrial. (Lula..., 2008, tradução nossa)

Para compreender a mudança da posição brasileira sobre a integração regional e o Mercosul é preciso considerar as grandes mudanças internacionais que impactaram os Estados. Por um lado, como foi amplamente evidenciado pela crise financeira de 2008, houve uma redução da capacidade econômica norte-americana; por outro, cresceu o 
significado de outros países e regiões, constatação válida para todos os países, inclusive para os da América do Sul. Fator de grande impacto, cujas dimensões não eram previsíveis no início dos anos 1990, foi o extraordinário crescimento da China e da Ásia. Desde 1985, quando da aproximação Argentina-Brasil, ou desde 1991, com a criação do Mercosul, a geografia política e econômica internacional modificou-se profundamente. Waltz (2000, pp. 30, 32, tradução nossa) afirma que

a teoria nos permite dizer que uma nova balança de poder será constituída, mas não nos diz quanto tempo esse processo levará para concretizar-se. [...] o inevitável movimento da unipolaridade para multipolaridade não está acontecendo na Europa, mas na Ásia.

A reestruturação do poder mundial nos anos 2000, com o desenvolvimento focado em países não centrais, como demonstram o papel de Índia, Rússia e África do Sul, além da China, e as relativas mudanças na distribuição do comércio exterior brasileiro contribuíram para que a integração regional passasse a ter menor peso relativo nos projetos de inserção externa das elites brasileiras e do Estado. Tanto na perspectiva liberal quanto na nacional-desenvolvimentista, o Mercosul continuou importante como base da política brasileira, mas o foco de interesses foi reorientado e a ação empresarial e governamental passou a concentrar-se em outras direções. Segundo Guimarães (2006, p. 275),

é indispensável trabalhar de forma consistente e persistente em favor da emergência de um sistema mundial multipolar no qual a América do Sul venha a constituir um dos pólos e não ser apenas uma sub-região de qualquer outro pólo econômico ou político. 
Um dos fatores importantes que explicam essa reorientação pode ser dimensionado de forma precisa. Trata-se das mudanças ocorridas no comércio exterior do país. Do ponto de vista do Brasil, as exportações para os países que viriam a constituir o Mercosul, que em 1985 representavam 3,86\% do total, passaram a representar $17,37 \%$ em 1998 . No mesmo período, as importações evoluíram de $4,88 \%$ para $15,19 \%$ (Comisión Económica para América Latina y el Caribe, 2003). Além da evidente importância dessa evolução, a qualidade do comércio brasileiro intrazona é favorável, por ser relevante a presença de produtos e serviços de maior valor agregado, como veremos a seguir.

Os gráficos 1 e 2 mostram as mudanças ocorridas na estrutura do comércio exterior do Brasil a partir de 1991 até 2019; neles, apresentamos a evolução das importações e exportações e o percentual representado pelo Mercosul:

\section{Gráfico 1}

Participação do Mercosul nas exportações brasileiras

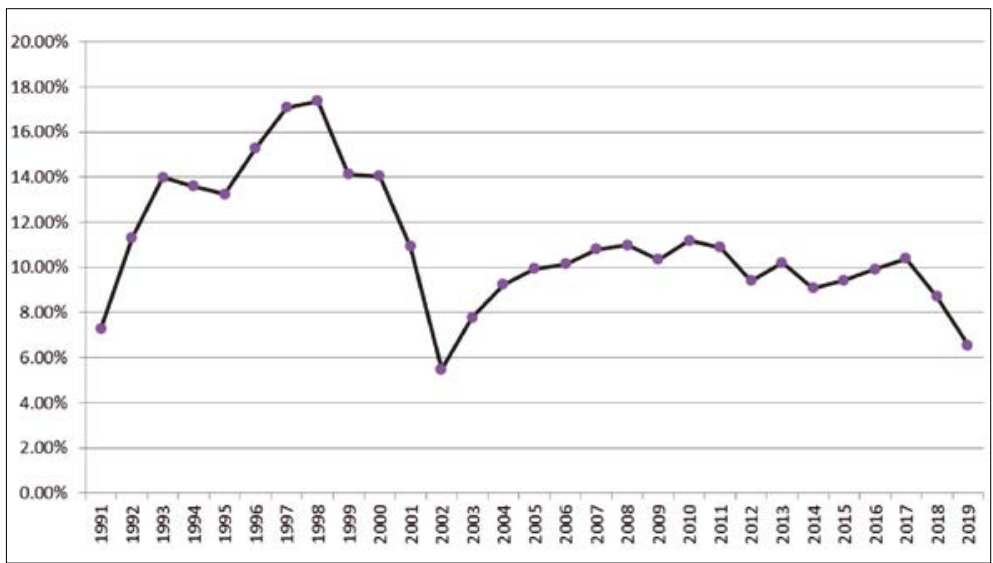

Fonte: Elaboração própria, com base em dados do Ministério da Indústria, Comércio Exterior e Serviços (MDIC).$^{5}$

5 Os dados podem ser conferidos no link: https://bit.ly/3vofmkV. 
Como é possível verificar pelos dados do Gráfico 1, em 1991 as exportações do Brasil para os países do Mercosul representavam 7,29\% do total. Em 1998, esse percentual atingiu 17,37\%. Em 2002, muito por conta da crise da Argentina de 2001, esse percentual caiu para 5,48\%, sendo retomado o crescimento nos anos seguintes até atingir o patamar de 11,19\% em 2010. Na segunda década dos anos 2000, a tendência geral foi de diminuição relativa (em alguns casos também absoluta) do peso do Mercosul no percentual das exportações brasileiras. Em 2011, as exportações para os países do Mercosul representavam 10,88\%; em 2019, esse valor caiu para $6,54 \%$, ou seja, para um patamar inferior ao verificado no início do Mercosul.

\section{Gráfico 2}

Participação do Mercosul nas importações brasileiras

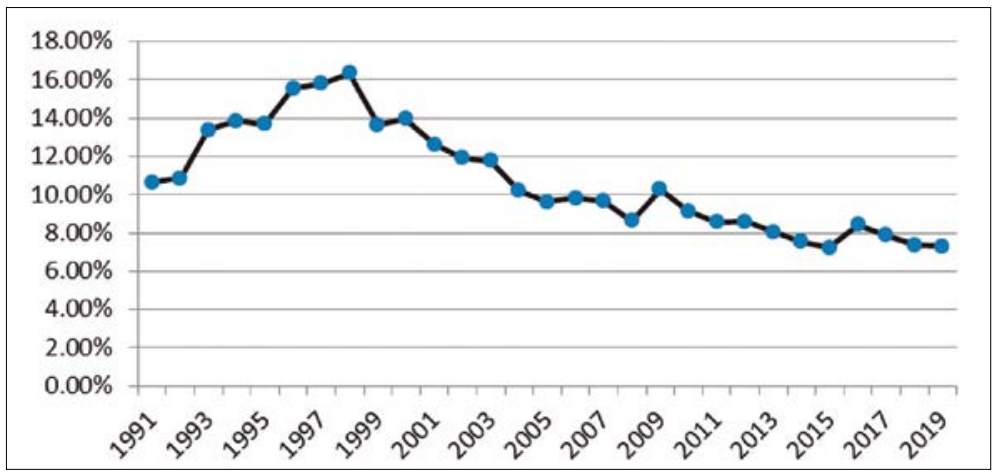

Fonte: Elaboração própria a partir de dados do MDIC e Banco Central.

Do ponto de vista das importações brasileiras (Gráfico 2), as oriundas dos países do Mercosul representavam 10,66\% do total em 1991. Em 1998, esse percentual atingiu a marca de $16,34 \%$, o maior valor durante todo o período de 1991 a 2019. Em 2002, as importações do Brasil oriundas dos sócios do Mercosul eram de 11,90\% e em 2010, último ano do governo Lula, haviam diminuído a 9,14\%. De 
forma similar ao ocorrido com as exportações, na segunda década dos anos 2000 as importações oriundas dos países do Mercosul apresentam tendência geral de queda relativa (às vezes absoluta também), ainda que menos acentuada do que a trajetória das exportações. Em 2011, do total das importações brasileiras, 8,56\% provinham do Mercosul. Em 2019, esse percentual se reduziu a $7,31 \%$.

\section{Gráfico 3}

Participação relativa de países e blocos nas exportações brasileiras

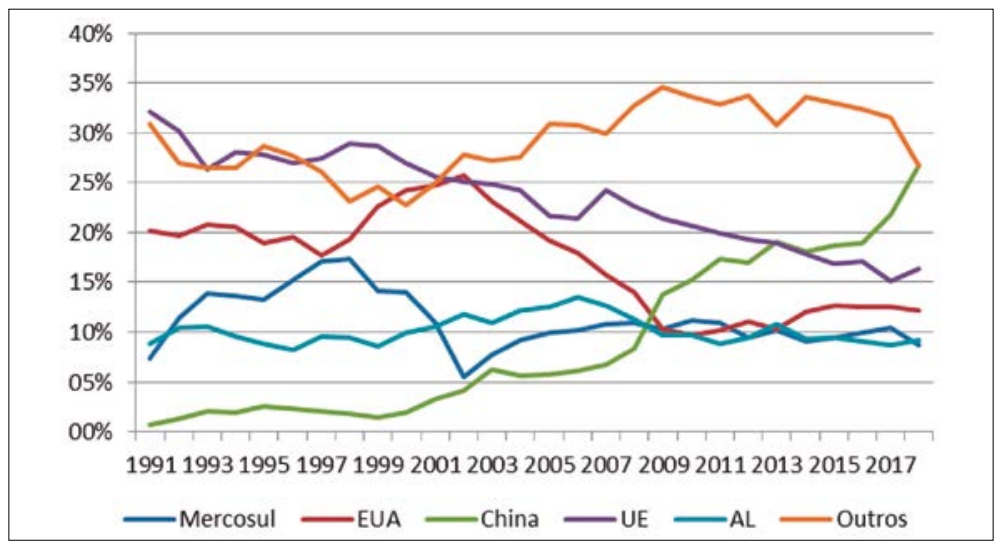

AL: América Latina; EUA: Estados Unidos; UE: União Europeia.

Fonte: Elaboração própria a partir de dados do Comtrade (https://comtrade. un.org).

Analisando o comércio exterior brasileiro de forma mais ampla (Gráfico 3), notam-se mudanças expressivas, impulsionadas principalmente pelo papel da China. Em 1991, a China representava $0,7 \%$ do total das exportações brasileiras; em 2000, passou a 2,0\%; em 2010, 15,2\%, e em 2018, 26,8\%. Os Estados Unidos em 1991 absorveram 20,2\%; em 2010, 9,6\%; em 2018, as exportações aos Estados Unidos representaram 12,2\% do total das exportações brasileiras. A América Latina, excluídos os países do Mercosul, representava em 1991 8,8\%; em 2010, 9,7\%; em 2018, 9,2\% do total 
das exportações brasileiras. Os países da União Europeia representavam $32,1 \%$ em 1991, passaram para $26,9 \%$ em 2000 e em 2018 diminuíram para 16,4\% do total.

Do ponto de vista do total das importações brasileiras (Gráfico 4), os Estados Unidos representavam 23,5\% em 1991, ao passo que a China representava 0,3\%. Em 2000, os Estados Unidos representavam 23,3\% das importações brasileiras, e a China, 2,2\%. Em 2010, os Estados Unidos representavam 15\%, e a China, 14,1\%. Finalmente, em 2018, os Estados Unidos representavam 16,2\%, e a China, 19,2\%. Ou seja, no decorrer do tempo, mesmo do ponto de vista das importações, a China se tornou a origem mais importante para o Brasil. A América Latina manteve-se em posição relativamente similar durante todo o período, representando algo em torno de $7 \%$ do total das importações brasileiras.

\section{Gráfico 4}

Participação relativa de países e blocos nas importações brasileiras

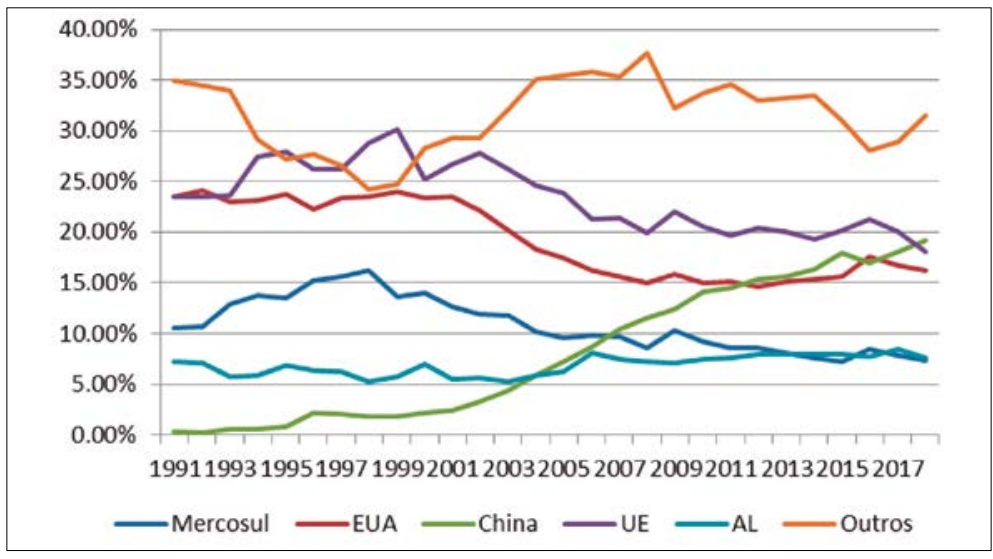

AL: América Latina; EUA: Estados Unidos; UE: União Europeia.

Fonte: Elaboração própria, com base em dados do Comtrade (https://comtrade. un.org).

Os fatores de inserção internacional são muitos, com destaque para os fluxos de capitais, de tecnologia, de valores, 
de cultura e relações de poder. O comércio é um dos fatores de grande importância, e o destino e a origem razoavelmente diversificados do comércio exterior brasileiro tendem a dar base aos argumentos universalistas de sua política externa. Essa diversificação ocorre também na Argentina, onde os produtos primários têm maior importância. O principal parceiro comercial do Brasil no ano 2000 eram os Estados Unidos, com 23,92\% das exportações e 23,3\% das importações. O segundo parceiro era a Argentina, com $11,32 \%$ das exportações e 12,26\% das importações. Como podemos ver nas tabelas 2 e 3, a China não estava nem entre os dez primeiros. Já em 2010, a China assumiu a primeira colocação nas exportações e a segunda colocação nas importações brasileiras, ficando a Argentina em terceiro lugar. Em 2019, a China assumiu a primeira colocação nos dois rankings, de importação e de exportação, e os Estados Unidos ficaram em segundo.

40 O comércio com a Argentina, e mais em geral com o Mercosul, que se recupera depois da crise aguda ocorrida de 1999 até 2002, não mais alcança, em termos relativos, o auge de 1998. Como pode ser visto nos gráficos 1 e 2, as relações comerciais com o Mercosul se recuperam parcialmente após 2002, mas seu significado relativo não mais retomou o papel alcançado na década de 1990.

Sinalizada esta situação, permanece importante notar, como já ressaltamos, que a contribuição da região ao superávit comercial brasileiro é significativa. Mais importante lembrar que se trata de produtos de maior valor agregado. Ainda assim, há uma diminuição do market share do bloco regional nas relações comerciais brasileiras, já que o maior crescimento do comércio nacional se dá em relação a países importadores de commodities, com destaque para a China. O debate interno a respeito da desindustrialização, que em 2020 permanece estagnada, sem qualquer horizonte de solução, fortalece-se neste contexto. 
Tabela 2

Dez principais destinos das exportações do Brasil em 2000, 2010 e 2019 em valores absolutos (US\$) e participação relativa (\%)

\begin{tabular}{|c|c|c|c|c|c|c|c|c|c|c|c|}
\hline & Países & 2000 (USD) & $\%$ & & Países & 2010 (USD) & $\%$ & & Países & 2019 (USD) & $\%$ \\
\hline 1 & $\begin{array}{l}\text { Estados } \\
\text { Unidos }\end{array}$ & $13,160,699,765$ & 23.92 & 1 & China & $30,747,553,704$ & 15.24 & 1 & China & $63,357,520,588$ & 28.11 \\
\hline 2 & Argentina & $6,229,543,769$ & 11.32 & 2 & $\begin{array}{l}\text { Estados } \\
\text { Unidos }\end{array}$ & $19,300,906,943$ & 9.56 & 2 & $\begin{array}{l}\text { Estados } \\
\text { Unidos }\end{array}$ & $29,715,863,527$ & 13.18 \\
\hline 3 & $\begin{array}{l}\text { Países } \\
\text { Baixos }\end{array}$ & $2,794,779,576$ & 5.08 & 3 & Argentina & $18,507,273,060$ & 9.17 & 3 & $\begin{array}{l}\text { Países } \\
\text { Baixos }\end{array}$ & $10,125,900,763$ & 4.49 \\
\hline 4 & Alemanha & $2,524,701,057$ & 4.59 & 4 & $\begin{array}{l}\text { Países } \\
\text { Baixos }\end{array}$ & $10,225,857,321$ & 5.07 & 4 & Argentina & $9,791,474,547$ & 4.34 \\
\hline 5 & Japão & $2,471,254,287$ & 4.49 & 5 & Alemanha & $8,134,386,646$ & 4.03 & 5 & Japão & $5,431,769,382$ & 2.41 \\
\hline 6 & Itália & $2,142,988,525$ & 3.90 & 6 & Japão & $7,140,402,276$ & 3.54 & 6 & Chile & $5,162,879,630$ & 2.29 \\
\hline 7 & Bélgica & $1,778,417,889$ & 3.23 & 7 & $\begin{array}{l}\text { Reino } \\
\text { Unido }\end{array}$ & $4,625,093,694$ & 2.29 & 7 & México & $4,898,455,548$ & 2.17 \\
\hline 8 & França & $1,729,729,489$ & 3.14 & 8 & Chile & $4,256,776,051$ & 2.11 & 8 & Alemanha & $4,731,497,703$ & 2.10 \\
\hline 9 & México & $1,709,783,257$ & 3.11 & 9 & Itália & $4,232,361,792$ & 2.10 & 9 & Espanha & $4,042,567,106$ & 1.79 \\
\hline 10 & $\begin{array}{l}\text { Reino } \\
\text { Unido }\end{array}$ & $1,496,503,491$ & 2.72 & 10 & Rússia & $4,147,690,633$ & 2.06 & 10 & $\begin{array}{l}\text { Coreia do } \\
\text { Sul }\end{array}$ & $3,449,684,302$ & 1.53 \\
\hline
\end{tabular}

USD: dólar americano.

Fonte: Samurio, Barros e Severo (2019) para 2000 e 2010 e MDIC para 2019.

\section{Tabela 3}

Dez principais origens das importações do Brasil em 2000, 2010 e 2019 em valores absolutos (US\$) e participação relativa (\%)

\begin{tabular}{|c|c|c|c|c|c|c|c|c|c|c|c|}
\hline & Países & 2000 (USD) & $\%$ & & Países & 2010 (USD) & $\%$ & & Países & 2019 (USD) & $\%$ \\
\hline 1 & $\begin{array}{l}\text { Estados } \\
\text { Unidos }\end{array}$ & $12,906,099,243$ & 23.09 & 1 & $\begin{array}{l}\text { Estados } \\
\text { Unidos }\end{array}$ & $27,038,687,487$ & 15.24 & 1 & China & $35,270,816,762$ & 29.89 \\
\hline 2 & Argentina & $6,849,829,801$ & 12.26 & 2 & China & $25,591,460,070$ & 9.56 & 2 & $\begin{array}{l}\text { Estados } \\
\text { Unidos }\end{array}$ & $30,090,157,711$ & 16.97 \\
\hline 3 & Alemanha & $4,445,211,380$ & 7.95 & 3 & Argentina & $14,433,416,651$ & 9.17 & 3 & Argentina & $10,552,232,182$ & 5.95 \\
\hline 4 & Japão & $2,970,860,904$ & 5.32 & 4 & Alemanha & $12,553,495,025$ & 5.07 & 4 & Alemanha & $10,280,263,597$ & 5.80 \\
\hline 5 & Itália & $2,171,362,283$ & 3.88 & 5 & $\begin{array}{l}\text { Coreia do } \\
\text { Sul }\end{array}$ & $8,425,993,375$ & 4.03 & 5 & $\begin{array}{l}\text { Coreia do } \\
\text { Sul }\end{array}$ & $4,705,681,345$ & 2.65 \\
\hline 6 & França & $1,858,380,051$ & 3.33 & 6 & Japão & $6,979,711,623$ & 3.54 & 6 & Índia & $4,257,612,842$ & 2.40 \\
\hline 7 & Argélia & $1,508,469,854$ & 2.70 & 7 & Nigéria & $5,925,152,202$ & 2.29 & 7 & México & $4,196,694,599$ & 2.37 \\
\hline 8 & $\begin{array}{c}\text { Coreia do } \\
\text { Sul }\end{array}$ & $1,439,468,186$ & 2.58 & 8 & Itália & $4,837,793,744$ & 2.11 & 8 & Japão & $4,094,098,846$ & 2.31 \\
\hline 9 & Venezuela & $1,327,901,894$ & 2.38 & 9 & França & $4,800,675,893$ & 2.10 & 9 & Itália & $4,041,399,190$ & 2.28 \\
\hline 10 & $\begin{array}{l}\text { Reino } \\
\text { Unido }\end{array}$ & $1,223,307,927$ & 2.19 & 10 & Índia & $4,243,145,061$ & 2.06 & 10 & Rússia & $3,680,499,839$ & 2.08 \\
\hline
\end{tabular}

USD: dólar americano.

Fonte: Samurio, Barros e Severo (2019) para 2000 e 2010 e MDIC para 2019. 
Como já afirmado anteriormente, o crescimento da economia mundial a partir de 2001, com destaque para o papel da China e da Ásia, a ênfase atribuída pelo Brasil às negociações na OMC como forma de fortalecer suas posições e a alta do preço das commodities desde 2003 (Prates, 2006) contribuíram para que setores empresariais e grupos importantes da alta administração pública buscassem reorientar o foco de seus interesses. O comportamento brasileiro na crise financeira e econômica de 2008 sugere que a ênfase na busca de um sistema mundial multipolar e do fim do unilateralismo se apoiou na percepção de que a maximização de capacidades ocorre pela participação em diversos foros, políticos e econômicos, regionais e multilaterais. O dinamismo da atuação brasileira no G20 financeiro e, ao mesmo tempo, as dificuldades para a coordenação regional de políticas evidenciam isso. O então presidente Lula da Silva, ao fim da Cúpula do G20 financeiro sobre economia mundial e mercados financeiros, realizada em Washington em novembro de 2008, concluiu: "o dado concreto é que, pela força política, pela representação dos países que foram inseridos no G20, eu penso que não tem mais nenhuma lógica tomar decisões sobre economia, sobre política, sem levar em conta esse fórum de hoje" (Cúpula..., 2008). Fica clara a expectativa do governo brasileiro quanto às negociações globais.

O Mercosul obteve relativo sucesso em termos de crescimento do seu intercâmbio extrabloco, conforme a Tabela 4. Isso se expressa nos números da balança comercial, quando a evolução do comércio exterior total do bloco foi razoavelmente positiva, passando de cerca de US\$ 169 bilhões em 1994 e chegando a quase US\$ 580 bilhões em 2014, diminuindo para pouco mais de US\$ 506 bilhões em 2018.

Conforme a Tabela 4, o comércio intra-Mercosul passou de cerca de US $\$ 41$ bilhões em 1994 para cerca de US\$ 63 bilhões em 1998, um crescimento de 53\% em quatro anos. Em 2002 houve um recuo expressivo e em 2010 
atingiu-se a relevante marca de mais de US\$100 bilhões, com diminuição para US\$ 88 bilhões em 2014 e US $\$ 80$ bilhões em 2018, evidenciando oscilações significativas, consequências das crises econômicas e políticas de Argentina e Brasil.

A expectativa era que a ênfase universalista gerasse externalidades positivas em termos de convergência de posições, tanto nos fóruns multilaterais quanto nos regionais, mas ela foi atendida apenas parcialmente. O Mercosul, a União de Nações Sul-Americanas (Unasul) e as relações com os países associados seriam fortalecidos como consequência do fim do unilateralismo e pela afirmação do multilateralismo (Vigevani e Ramanzini Júnior, 2014).

Tabela 4

Fluxo anual de comércio intra e extra-Mercosul

\begin{tabular}{|c|c|c|c|c|c|c|}
\hline Ano & $\begin{array}{c}\text { Comércio } \\
\text { Total }\end{array}$ & & $\begin{array}{l}\text { Comércio } \\
\text { intra- } \\
\text {-Mercosul }\end{array}$ & & $\begin{array}{l}\text { Comércio } \\
\text { extra- } \\
\text {-Mercosul }\end{array}$ & \\
\hline & $\begin{array}{c}2018 \\
\text { (em } \\
\text { bilhões de } \\
\text { US\$) }\end{array}$ & $(\Delta \%)$ & $\begin{array}{c}2018 \\
\text { (em } \\
\text { bilhões de } \\
\text { US\$) }\end{array}$ & $(\Delta \%)$ & $\begin{array}{c}2018 \\
\text { (em } \\
\text { bilhões } \\
\text { de US\$) }\end{array}$ & $(\Delta \%)$ \\
\hline 1994 & 210.659 & - & 41.398 & - & 169.261 & - \\
\hline 1998 & 277.608 & $31,78 \%$ & 63.583 & $53,59 \%$ & 214.025 & $26,45 \%$ \\
\hline 2002 & 209.678 & $-24,47 \%$ & 30.623 & $-51,84 \%$ & 179.055 & $-16,34 \%$ \\
\hline 2006 & 407.161 & $94,18 \%$ & 66.038 & $115,65 \%$ & 341.123 & $90,51 \%$ \\
\hline 2010 & 622.479 & $52,88 \%$ & 100.372 & $51,99 \%$ & 522.107 & $53,06 \%$ \\
\hline 2014 & 668.376 & $7,37 \%$ & 88.728 & $-11,60 \%$ & 579.648 & $11,02 \%$ \\
\hline 2018 & 586.885 & $-12,19 \%$ & 80.422 & $-9,36 \%$ & 506.463 & $-12,63 \%$ \\
\hline $\begin{array}{c}\Delta \% 2018- \\
1994\end{array}$ & & $178.59 \%$ & & $94,26 \%$ & & $199,22 \%$ \\
\hline
\end{tabular}

US\$: dólar americano; $\Delta \%$ : variação da porcentagem.

Fonte: Elaboração própria a partir de dados do Comtrade (https://comtrade. un.org). 
No entanto, o agravamento da crise doméstica no Brasil, as mudanças políticas em vários países da América do Sul e as incertezas do cenário internacional resultaram em um clima de crescente desconfiança quanto ao futuro, principalmente por parte das elites.

Nos anos 2015 e 2016 é possível verificar uma importante mudança nas percepções e expectativas dos líderes políticos e sociais sobre a situação do país e do mundo, como pode ser visto nos dados apresentados a seguir, que foram extraídos do levantamento "O Brasil, as Américas e o mundo segundo a opinião do público e dos líderes: 2010/2011 - 2014/2016" (Almeida et al., 2017). ${ }^{6}$ Assim, em comparação com o período 2010-2011, é possível identificar uma significativa mudança de percepção sobre: (1) a piora da situação econômica do país em relação ao passado, que saltou de $2 \%$ para 75,8\%; (2) a discordância em relação ao encaminhamento da política exterior, que aumentou de $4422,5 \%$ para 36,7\%; (3) a importância do Brasil no mundo em comparação com os dez anos anteriores, antes vista por $97 \%$ dos líderes como mais importante, e que passou para $62,5 \%$; e (4) as expectativas de melhoria sobre a situação do mundo nos próximos dez anos, que passou de $69 \%$ para 50,8\%.A política brasileira manteve interesse regional até 2015, inclusive sul-americano, visível na busca pela continuidade da Unasul. Seu aprofundamento, em particular no que se refere ao Mercosul, vincula-se à visão de mundo dos governos do Partido dos Trabalhadores. O impeachment, por meio de um golpe parlamentar consumado em maio de 2016, rompeu esta perspectiva. Deve ser assinalado que nos dois governos Rousseff, desde 2011, a crescente oposição

\footnotetext{
6 Este levantamento foi realizado pelo Instituto de Relações Internacionais da Universidade de São Paulo em parceria com o Centro Brasileiro de Análise e Planejamento. As opiniões dos líderes foram levantadas nos períodos 2010-2011 e 2015-2016 e os dados foram organizados de forma a permitir a comparação entre os dois momentos (Almeida et al., 2017).
} 
conservadora e de direita radical dificultava a perspectiva de consolidação da integração. A partir daquele ano, o cenário global enveredou para um revigoramento do unilateralismo, ainda mais fortemente com o início da administração Trump em janeiro 2017 nos Estados Unidos, cujo desdobramento hemisférico foi a busca da reinserção dos países considerados dissidentes no sistema liderado pelos próprios Estados Unidos. O desdobramento a partir daí, para o Brasil, foi o enfraquecimento dos órgãos regionais, no caso da Unasul seu fim de facto, ainda que não de direito, e o crescente entrelaçamento da política interna com a externa, com significativo abandono do interesse. Na gestão Bolsonaro, a questão das relações regionais, sobretudo em sua coincidência com a administração Trump, concentrou-se no apoio às ameaças de intervenção na Venezuela.

\section{Considerações finais}

No início de 2021, olhando retrospectivamente a trajetória do Mercosul, devemos considerar que os atores domésticos pró-integração tiveram iniciativa e capacidade nos anos 1980 para superar longas fases históricas em que a questão da integração regional havia se colocado apenas de forma parcial. Estes atores, entre eles diplomatas, militares, cientistas e técnicos nos campos de energia, políticos e empresários interessados na ampliação do mercado, viabilizaram a aproximação Argentina-Brasil e a mudança no padrão de relacionamento entre os dois países. Contudo, as dificuldades para a construção de políticas públicas convergentes com a integração e a ampliação da interdependência econômica, ao final dos anos 1990, inclusive as resistências encontradas, permitiram no decorrer dos anos 2000, mesmo no período desenvolvimentista-distributivista, o fortalecimento de atores que passaram a valorizar ideias, projetos e interesses que não confluíam com a integração regional. 
Mostramos que, no núcleo do Estado brasileiro e de suas elites, as posições oscilaram ao longo do tempo entre ideias que colocaram a integração regional e o Mercosul como interesses centrais e estruturais e outras que os viram como instrumentais. É esta alternância que permitiu a forte atenuação do interesse ao longo do tempo e que contribuiu para o seu declínio como se vislumbra desde os últimos anos de 2010.

Houve avanços históricos em pontos importantes, como o desaparecimento de hipóteses de guerra na Bacia do Prata, tema de preocupação secular para os quatro países do Mercosul. Ao mesmo tempo, o estágio atual, de meados dos anos 2010 até 2020, sinaliza ações de cooperação e integração de baixa intensidade. A crise institucional brasileira, aguçada em 2016, consolidou o estágio de baixa demanda pela integração, como sinalizado pela quebra do impulso regional de algumas grandes empresas, empreiteiras e outras, como a Petrobrás, e de alguns bancos, a diminuição dos investimentos do Banco Nacional de Desenvolvimento Econômico e Social, e o menor interesse comum por áreas de alta tecnologia (aeronáutica, segurança etc.).

As forças econômicas internas nos países do Mercosul, e no Brasil em particular, favoráveis à integração foram se enfraquecendo. Isto ajuda a compreender as razões pelas quais a integração permaneceu parte integrante da agenda de política exterior, mas tendo uma continuidade de baixa intensidade.

De forma retrospectiva, podemos considerar que o contexto internacional, seja de crescimento, seja de crise, não favoreceu a integração na América do Sul. Os fatores desestabilizadores ou que não favoreceram a integração são inúmeros, exógenos à região, como as consequências das políticas dos Estados Unidos ou as relações econômicas com a China baseadas na exportação de commodities, ou 
endógenos, como a fragilidade dos Estados e a baixa capacidade de desenvolver a interdependência econômica.

$\mathrm{Na}$ primeira década dos anos 2000, as dificuldades estruturais foram parcialmente substituídas pela ideia de um Mercosul social, político, participativo e cultural. Os esforços de integração cultural, de compartilhamento de experiências de políticas sociais (educação, saúde, seguridade social etc.), as buscas por maior integração política (Parlamento) e ações compensatórias (Fundo para a Convergência Estrutural do Mercosul), e sobretudo as afinidades entre as lideranças políticas são aspectos relevantes, mas insuficientes para garantir a integração regional.

Um processo de integração se consolida quando interesses econômicos ou comunidades epistêmicas tenham atendidos seus objetivos relevantes. Fator explicativo da continuidade do Mercosul são esses interesses econômicos. Do ponto de vista do Brasil, por um lado explicam a baixa intensidade, e por outro a continuidade do Mercosul, como evidenciado no documento da Confederação Nacional da Indústria (2020). O comércio intrabloco, de 1991 a 2018, diminuiu de $9 \%$ para $8 \%$, demonstrando que o objetivo comercialista também não foi alcançado.

As ações visando integração e cooperação não pareceram suficientes para neutralizar as debilidades estruturais dos países, ou para inserir a dinâmica regional nas agendas das políticas domésticas. Na integração regional entre países em desenvolvimento, é difícil construir políticas compensatórias que facilitem a adesão social a um bloco regional. As situações de afinidades genéricas entre os governos, como aquelas da primeira década dos anos 2000, não foram suficientes para aprofundar as políticas de integração.

Na segunda metade dos anos 2010, a ascensão de governos conservadores, estreitamente enraizados em visões pró-mercado, teve como consequência a desestruturação de órgãos regionais e o enfraquecimento do Mercosul. A 
crescente instabilidade regional teve também outras consequências, como a incapacidade de oferecer sustentação a governos legítimos (Paraguai, Bolívia, Brasil) ou de mediar soluções de forte radicalização, como na Venezuela. Sem que novas instituições efetivas surgissem, o Foro para el Progreso de América del Sur (Prosur ou Fórum Prosul), iniciativa chilena do presidente Sebastián Piñera, constituído em março de 2019, foi criado nesse contexto (Sanahuja, 2019), com oito países sul-americanos. Ao contrário da Unasul, que englobava toda a região, o Prosul é uma iniciativa fracionada que enfatiza os elementos de diferenciação entre os países (Barros e Gonçalves, 2019), contribuindo para aumentar a vulnerabilidade da região, particularmente em relação a atores externos, sobretudo os Estados Unidos, fazendo com que alguns países voltem a ser cenário de disputas geopolíticas. O Prosul nem se propõe a qualquer tentativa de articulação de capacidades.

A mudança de curso no Brasil, a partir de 2016, no sentido de maior aproximação com os Estados Unidos e a diminuição da relevância do Mercosul evidenciam que as políticas anteriores não foram capazes e não puderam ampliar a interdependência ou a institucionalidade do bloco, de modo a garantir a sua continuidade nas situações de instabilidade política. As dificuldades analisadas para a consolidação da integração, de 1991 a 2016, explicam em parte por que mudanças radicais, como as observadas na administração Bolsonaro, produzem limitada reação da opinião pública, ao menos até 2020.

A indefinição e as instabilidades do sistema internacional sugeriam uma estratégia de inserção internacional flexível a mudanças. Essa noção esteve presente nas formulações brasileiras em relação ao Mercosul, principalmente na defesa da intergovernamentalidade como princípio institucional da integração. Essa perspectiva foi mantida de 1991 
até hoje, porque adapta o processo de integração regional às diferentes interpretações dos governos que se sucedem.

Para o Brasil e para o Mercosul, conforme argumentamos, as dificuldades para a afirmação da integração não estiveram vinculadas à vontade política (algo que se modifica apenas em 2019, com a administração Bolsonaro), mas derivam de mudanças profundas no sistema internacional e no comércio exterior do país, que se referem à estrutura econômica, aos fluxos de comércio, de investimentos, de tecnologia e ao poder político, militar e cultural. A partir dos anos 2000, na sociedade e no Estado brasileiro, os interesses e as concepções de autonomia e universalismo, a busca pelo fim do unilateralismo e o fortalecimento do multilateralismo - objetivos estes que em algumas fases se superpuseram e coincidiram com o projeto de integração regional, particularmente na relação com a Argentina e com o Mercosul - pareceram encontrar crescentes dificuldades para se compatibilizar.

Mesmo diante de tantas dificuldades, crises diplomáticas, problemas econômicos e instabilidade política, o Mercosul se mostrou muito resiliente. No entanto, em meio à tempestade atual, permanece a dúvida sobre a resiliência do Mercosul diante de uma conjuntura crítica marcada pela pandemia do novo coronavírus e, ao mesmo tempo, pelas consequências das ações tomadas pela administração Bolsonaro com respeito à política externa e, em especial, aos processos de cooperação e integração regional.

\section{Marcelo Passini Mariano}

Professor de Relações Internacionais da Universidade Estadual Paulista (UNESP) e do Programa de Pós-graduação em Relações Internacionais San Tiago Dantas (UNESP / UNICAMP / PUC-SP); Pesquisador da Rede de Pesquisa em Política Externa e Regionalismo (REPRI); Coordenador do 
Laboratório de Novas Tecnologias de Pesquisa em Relações Internacionais (LANTRI).

\section{Haroldo Ramanzini Júnior}

Professor Associado do Instituto de Economia e Relações Internacionais da Universidade Federal de Uberlândia (UFU), Pesquisador da Rede de Pesquisa em Política Externa e Regionalismo (REPRI), do Instituto Nacional de Ciência e Tecnologia de Estudos sobre os Estados Unidos (INCTINEU) e do Centro de Estudos Globais da Universidade de Brasília (UNB).

\section{Tullo Vigevani}

Professor de Ciência Política e Relações Internacionais da Universidade Estadual Paulista (UNESP); Pesquisador do Centro de Estudos de Cultura Contemporânea (CEDEG) e do Instituto Nacional de Ciência e Tecnologia de Estudos sobre os Estados Unidos (INCT-INEU).

\section{Bibliografia}

ALMEIDA, Maria Hermínia Tavares de et al. 2017. O Brasil, as Américas e o mundo segundo a opinião do público e dos lideres: 2010/2011 - 2014/2016. São Paulo: Cebrap. Disponível em: https://bit.ly/3dt5cJX. Acesso em: 15 fev. 2021.

ALMEIDA, Paulo Roberto de. 1993. O Mercosul: no contexto regional e internacional. São Paulo: Edições Aduaneiras.

BANCO CENTRAL DO BRASIL. SGS - Sistema Gerenciador de Séries Temporais. Disponível em: https://bit.ly/3biAdyv. Acesso em: 10 maio 2021.

BARBOSA, Rubens A. 1996. O lugar do Brasil no mundo. Política Externa, v. 5 , n. 2, pp. $62-82$.

BARROS, Pedro Silva; GONÇALVES, Julia de Souza Borba. 2019.

Fragmentação da governança regional: o Grupo de Lima e a política externa brasileira (2017-2019). Mundo e Desenvolvimento, v. 2, n. 3, pp. 6-39.

BRASIL. Ministério das Relações Exteriores. 1991. Brasil, Argentina, Uruguai e Paraguai criam Mercado Comum do Sul 
(Mercosul). Resenha de Política Exterior do Brasil, n. 68, 26 mar. 1991. (Nota à imprensa).

CÚPULA estabelece medidas e prazos anticrise. 2008. Gazeta Mercantil, 17 nov. 2008.

CAMARGO, Sonia de. 2006. Mercosul: crise de crescimento ou crise terminal? Lua Nova, n. 68, pp. 57-90.

CANDEAS, Alessandro Warley. 2005. Relações Brasil-Argentina: uma análise dos avanços e recuos. Revista Brasileira de Política Internacional, v. 48 , n. 1 , pp. $1-36$.

CIA. 2021. The world factbook. Washington, DC: Central Intelligence Agency. Disponível em: https://bit.ly/2R7i2EA. Acesso em: 1 fev. 2021.

COMISIÓN ECONÓMICA PARA AMÉRICA LATINA Y EL CARIBE. 2003. Panorama de la inserción internacional de América Latina y el Caribe, 20002001. Santiago: Cepal.

CONFEDERAÇÃO NACIONAL DA INDÚSTRIA. 2020. Impactos jurídicos da saída do Mercosul. Brasília: CNI.

DAHL, Robert. 1958. A critique of the ruling elite model. The American Political Science Review, v. 52, n. 2, pp. 463-469.

DESIDERÁ NETO, Walter A. (org.). 2014. O Brasil e as novas dimensões da integração regional. Rio de Janeiro: Ipea.

EMPRESÁRIOS discutem o Mercosul. 2004. Valor Econômico, 16 nov. 2004.

FAORO, Raymundo. 1975. Os donos do poder: formação do patronato político brasileiro. Porto Alegre: Globo.

FERNANDES, Florestan. 1987. A revolução burguesa no Brasil: ensaio de interpretação sociológica. São Paulo: Guanabara.

FMI. 2019. World economic outlook. Washington, DC: Fundo Monetário Internacional. Disponível em: https://bit.ly/32VP1hU. Acesso em: 1 fev. 2021.

FONSECA, Roberto Giannetti da; MARCONINI, Mário. 2006. Inserção internacional e o comércio exterior brasileiro. Revista Brasileira de Comércio Exterior, n. 87, pp. 5-9.

FONSECA JÚNIOR, Gelson. 1998. A legitimidade e outras questões internacionais. São Paulo: Paz e Terra.

GAZZOLA, Ana Elisa Thomazella. 2017. O Mercosul em dois momentos: uma análise a partir das revisões institucionais de 1994 e 2004. Dissertação de Mestrado em Relações Internacionais. São Paulo: Unesp: Unicamp: PUC-SP.

GONÇALVES, José Botafogo; LYRIO, Maurício Carvalho. 2003. Aliança estratégica entre Brasil e Argentina: antecedentes, estado atual e perspectivas. Cebri Dossiê, v. 2, ano 2. 
GUIMARÃES, Samuel P. 2006. Desafios brasileiros na era dos gigantes. Rio de Janeiro: Contraponto.

HAAS, Ernst. 1958. The uniting of Europe. Indiana: University of Notre Dame Press.

HUMMEL, Felix; LOHAUS, Mathis. 2012. Mercosur: integration through presidents and paymasters. In: BÖRZEL, Tanja A.;

GOLTERMANN, Lukas; STRIEBINGER, Kai. Roads to regionalism: genesis, design, and effects of regional organizations. Aldershot: Ashgate: Routledge, pp. 1-28. Disponível em: https://bit.ly/3aFVX71. Acesso em: 1 fev. 2021

KACOWICZ, Arie M. 2016. Latin America in the New World Security Architecture. In: MARES, David; KACOWICZ, Arie (org.) Routledge handbook of Latin American Security. New York: Routledge, capítulo 28.

KRAPOHL, Sebastian. 2020. Games regional actors play: dependency, regionalism, and integration theory for the Global South. Journal of International Relations and Development, v. 23, pp. 840-870.

LIMA, Maria Regina Soares de. 2018. A Agência da Política Externa Brasileira: uma análise preliminar. In: DESIDERÁ NETO, Walter A. et al. (org.). Política externa brasileira em debate: dimensões e estratégias de inserção internacional no pós-crise de 2008. Brasília: Ipea: Funag, pp. 39-53.

LULA DA SILVA, Luiz Inácio. 2006. Discurso do presidente da República, Luiz Inácio Lula da Silva, por ocasião do encerramento da XXX Cúpula dos Chefes de Estado do Mercosul. Córdoba, jul. 2006. Disponível em: https://bit.ly/3e787qK. Acesso em: 2 dez. 2006.

LULA, en exclusiva con Clarín: "no existe ninguna hipótesis de que Brasil se juegue solo". 2008. Clarín, 7 set. 2008.

MARIANO, Marcelo Passini. 2015. A política externa brasileira e a integração regional: uma análise a partir do Mercosul. São Paulo: Editora Unesp.

MATTLI, Walter. 1999a. Explaining regional integration outcomes. Journal of European Public Policy, v. 6, n. 1, pp. 1-27.

MATTLI, Walter. 1999b. The logic of regional integration: Europe and beyond. Cambridge: Cambridge University Press.

MDIC. Exportação e Importação Geral. Disponível em: https://bit.ly/2RE6IAq. Acesso em: 10 maio 2021.

MELLO, Flávia de Campos. 2000. Regionalismo e inserção internacional: continuidade e transformação da política externa brasileira nos anos 90. Tese de Doutorado em Ciência Política. São Paulo: Universidade de São Paulo. 
MORAVCSIK, Andrew. 1995. Liberal intergovernmentalism and integration: a rejoinder. Journal of Common Market Studies, v. 33, n. 4, pp. 611-628.

MOREIRA, Marcílio Marques. 1989. O Brasil no contexto internacional do final do século XX. Lua Nova, n. 18, pp. 5-23.

PAIKIN, Damian; DULCICH, Federico. 2017. El sexto socio del Mercosur: un estudio sobre la penetración importadora china y su impacto en el comercio intrarregional. Revista Perspectivas de Políticas Públicas, v. 6 , n. 12, pp. 395-414.

PNUD. 2019. Relatório do desenvolvimento humano 2019: além do rendimento, além das médias, além do presente: desigualdades no desenvolvimento humano no século XXI. New York: United Nations. Disponível em: https://bit.ly/3nvuFpd. Acesso em: 1 fev. 2021.

PRATES, Daniela M. 2006. A inserção externa da economia brasileira no governo Lula. Política Econômica em Foco, n. 7, pp. 119-151.

RAMANZINI JÚNIOR, Haroldo; LUCIANO, Bruno Theodoro. 2020.

Regionalism in the Global South: Mercosur and Ecowas in trade and democracy protection. Third World Quarterly, v. 41, n. 9, pp. 1498-1517. RAMANZINI JÚNIOR, Haroldo; MARIANO, Marcelo Passini. 2018. As relações com a América do Sul (2008-2015). In: DESIDERÁ NETO, Walter et al. (org.). Política externa brasileira em debate: dimensões e estratégias de inserção internacional no pós-crise de 2008. Brasília: Ipea: Funag, pp. 235-271.

RIGGIROZZI, Pía; TUSSIE, Diana. 2012. The rise of post-hegemonic regionalism: the case of Latin America. New York: Springer.

SAMURIO, Sofia Escobar, BARROS, Pedro Silva; SEVERO, Luciano. 2019. O protagonismo do Brasil na integração sul-americana: uma análise das relações comerciais 2000-2018. Oikos, v. 18, n. 1, pp. 38-54.

SANAHUJA, José. 2019. La crisis de integración y el regionalismo en América Latina: giro liberal-conservador y contestación normativa. In: MESA, Manuela (coord.). Ascenso del nacionalismo y el autoritarismo en el sistema internacional. Madrid: Fundación Cultura de Paz, pp. 107-127.

SCHMITTER, Philippe C. 1970. A revised theory of regional integration. International Organization, v. 24, n. 4, pp. 836-868.

SCHMITTER, Philippe C. 2010. A experiência da integração europeia e seu potencial para a integração regional. Lua Nova, n. 80, pp. 9-44.

VADELL, Javier A.; GIACCAGLIA, Clarisa. 2020. El rol de Brasil en el regionalismo latinoamericano: la apuesta por una inserción internacional solitaria y unilateral. Foro Internacional, v. 60, n. 3 (241), pp. 1041-1080. 
VIGEVANI, Tullo; RAMANZINI JÚNIOR, Haroldo. 2014. Autonomia, integração regional e política externa brasileira: Mercosul e Unasul. Dados: Revista de Ciências Sociais, v. 57, n. 2, pp. 517-552.

VIGEVANI, Tullo; VEIGA, João Paulo Cândia. 1997. A integração industrial no Mercosul. In: ARBIX, Glauco; ZILBOVICIUS, Mauro (org.). De JK a FHC: a reinvenção dos carros. São Paulo: Scritta, pp. 329-355.

WALTZ, Kenneth N. 2000. Structural realism after the Cold War. International Security, v. 25, n. 1, pp. 5-41. 


\section{O BRASIL E 0 MERCOSUL: ATORES DOMÉSTICOS E OSCILAÇÕES DA POLÍTICA EXTERNA NOS ÚLTIMOS 30 ANOS}

MARCELO PASSINI MARIANO

HAROLDO RAMANZINI JÚNIOR

\section{TULLO VIGEVANI}

Resumo: $\mathrm{O}$ objetivo deste artigo é analisar o Mercosul na política externa brasileira no período de 1991 a 2021. Argumentaremos que há uma trajetória de gradual perda de centralidade do bloco para a política externa brasileira e de redução nos níveis de intercâmbio comercial. Assim, o declínio da prioridade do bloco para o Brasil, observado nos governos Temer e Bolsonaro, não pode ser considerado fato desenraizado de problemas que já se manifestavam nos governos anteriores, em verdade desde 1995, ainda que com diferentes características. Nestes trinta anos, as elites empresariais e políticas brasileiras não mantiveram o mesmo interesse pela integração. Do mesmo modo, as transformações do sistema internacional e a evolução que produziram na percepção das elites a respeito do papel que o Brasil deveria desempenhar no mundo não foram absorvidas como incentivos sistêmicos para o aprofundamento da integração regional. O bloco completa trinta anos demonstrando importante resiliência, apesar do contexto de menor engajamento dos países, dos efeitos acumulados das sucessivas crises políticas e comerciais e da diminuição da importância econômica em relação a outros parceiros extrabloco, fatores que colocam importantes interrogações em relação ao seu futuro.

Palavras-chave: Política Externa Brasileira; Mercosul; Integração Regional. 


\section{BRAZIL AND MERCOSUR: DOMESTIC ACTORS}

\section{AND FOREIGN POLICY FLUCTUATIONS IN THE LAST 30 YEARS}

Abstract: The purpose of this article is to analyze the role of Mercosur for Brazilian foreign policy from 1991 to 2021. We will argue that there is a path of gradual loss of centrality by the bloc for Brazilian foreign policy and a reduction in the levels of trade. Thus, the decline in the bloc's priority for Brazil, observed in Temer and Bolsonaro administrations, cannot be examined without referencing difficulties that had already manifested in previous governments, in fact since 1995, although with different characteristics. During these thirty years, Brazilian business and political elites have not maintained the same interest in integration. Likewise, the transformations of the international system and the evolution that they produced in the perception of the elites regarding the role that Brazil should play in the world were not absorbed as systemic incentives for the deepening of regional integration. The bloc celebrates its 30th anniversary demonstrating an important resilience, despite the context of lesser engagement of the countries, the accumulated effects of successive political and trade crises and the diminishing economic importance in relation to other extra-bloc partners, factors that raise important questions in relation to its future.

Keywords: Brazilian Foreign Policy; Mercosur; Regional Integration.

Recebido: 02/02/2021 Aprovado: 16/03/2021 